\title{
A Glucosamine-Specific Lectin from Green Dragon No. 8 Beans (Phaseolus vulgaris) Induced Apoptosis on Nasopharyngeal Carcinoma Cells
}

\author{
Yau Sang Chan, ${ }^{1,2}$ Lixin Xia, ${ }^{1}$ and Tzi Bun $\mathrm{Ng}^{3}$ \\ ${ }^{1}$ State Key Laboratory of Respiratory Disease for Allergy at Shenzhen University, School of Medicine, Shenzhen University, \\ Nanhai Avenue 3688, Shenzhen, Guangdong 518060, China \\ ${ }^{2}$ Shenzhen Institutes of Advanced Technology, Chinese Academy of Sciences, School of Medicine, Shenzhen University, \\ Nanhai Avenue 3688, Shenzhen, Guangdong 518060, China \\ ${ }^{3}$ School of Biomedical Sciences, The Chinese University of Hong Kong, Lo Kwee Seong Integrated Biomedical Sciences Building, \\ Shatin, New Territories, Hong Kong \\ Correspondence should be addressed to Lixin Xia; xialixin@126.com and Tzi Bun Ng; b021770@mailserv.cuhk.edu.hk
}

Received 12 March 2015; Revised 6 July 2015; Accepted 7 July 2015

Academic Editor: Nunziatina De Tommasi

Copyright (c) 2015 Yau Sang Chan et al. This is an open access article distributed under the Creative Commons Attribution License, which permits unrestricted use, distribution, and reproduction in any medium, provided the original work is properly cited.

\begin{abstract}
A lectin exhibiting antiproliferative activity on tumor cell lines but devoid of antifungal activity has been purified from Phaseolus vulgaris cv. Green Dragon no. 8 seeds. The lectin was a $60 \mathrm{kDa}$ dimeric protein with two $30 \mathrm{kDa}$ subunits. It was a glucosaminespecific lectin as implied from the inhibitory effect of glucosamine on hemagglutinating activity of the lectin. The steps for isolation of the lectin involved Affi-gel blue gel (affinity gel), Mono Q (anion exchanger), and Superdex 75 column (size exclusion). The lectin was purified 20.8-fold from the crude extract of the beans. The purified lectin showed antiproliferative activity on breast cancer MCF7 cell line and nasopharyngeal cancer HONE1 and CNE2 cell lines, but a low activity on normal skin fibroblast HSF98 cell line. The lectin was shown to induce apoptosis on HONE1 cells, as indicated by increased phosphatidylserine externalization and mitochondrial depolarization. It also blocked HONE1 cell division and kept the cells at the $\mathrm{G}_{2} / \mathrm{M}$ phase of the cell cycle.
\end{abstract}

\section{Introduction}

Legumes are commonly used in cuisines worldwide. Especially for vegetarians, legumes act as an important part of their diet as they can provide a good source of proteins [1]. Most cooked legume proteins lose their biological activity and are digested and absorbed by our body [2]. In fact, many proteins with a variety of bioactivities are present in the raw beans. For example, some of them (e.g., defensins) can inhibit the growth of pathogenic fungi [3], and some of them (e.g., trypsin inhibitors) exhibit anti-insect activity [4]. In addition to defense against pathogens and predators, some of the bean proteins (e.g., phytohemagglutinins) also exert antiproliferative activities on cancer cell lines [5]. With such a diversity of bioactivities, bean proteins have aroused the interest of numerous researchers.
Kidney bean (Phaseolus vulgaris) is a major member of the family of leguminous plants. It is grown worldwide and is developed into many different cultivars. A number of the beans (e.g., red kidney bean, black beans) contain lectins $[6,7]$, and lectins from different cultivars exhibit different types of biological activities, to different extents [8]. For example, lectin from brown kidney beans but not in that of the Indian cultivar beans exhibited antiproliferative activity on tumor cell lines $[9,10]$. We may miss some lectins with potent biological activities from $P$. vulgaris cultivars that have not been investigated, and it is possible to seek new lectins with potential applications. Recently, we have detected the presence of a lectin from a new $P$. vulgaris cultivar, Green Dragon no. 8 beans, which has not been studied before. Here we tried to isolate the lectin from the beans and to study the biological activities in this newly identified lectin. 


\section{Materials and Methods}

2.1. Isolation of Lectin from Green Dragon No. 8 Beans. The beans were soaked in distilled water overnight, homogenized in a blender, and centrifuged twice at $30,000 \mathrm{~g}$ at $4^{\circ} \mathrm{C}$ for $25 \mathrm{~min}$. The supernatant was collected as crude extract of the beans. The extract was loaded onto an Affi-gel blue gel column preequilibrated with $10 \mathrm{mM}$ Tris- $\mathrm{HCl}(\mathrm{pH} 7.6)$ buffer. The unadsorbed materials were discarded, and the adsorbed fraction was collected by elution with $1 \mathrm{M} \mathrm{NaCl}$ in $10 \mathrm{mM}$ Tris- $\mathrm{HCl}$ ( $\mathrm{pH}$ 7.6) buffer. The fraction was dialyzed thoroughly in double-distilled water and lyophilized. It was resuspended in $10 \mathrm{mM}$ Tris- $\mathrm{HCl}$ ( $\mathrm{pH}$ 7.6) buffer and loaded onto a Mono Q column through FPLC using an AKTA purifier. The unadsorbed materials were discarded. The adsorbed materials were eluted using a 0 to $1 \mathrm{M} \mathrm{NaCl}$ gradient. The eluted fractions in the major absorbance peak containing the lectin were collected, dialyzed, lyophilized, and subjected to FPLC-gel filtration on a Superdex 75 column. The major absorbance peak eluted constituted purified lectin from the Green Dragon no. 8 beans [11].

2.2. Assay of Hemagglutinating Activity. Twofold serial dilution of protein sample was performed using $50 \mu \mathrm{L}$ PBS in a 96-well U-plate, followed by addition of $50 \mu \mathrm{L} 2 \%$ rabbit red blood cells. The plate was incubated for $1 \mathrm{hr}$ to allow the cells of the control (PBS only) to sink to the bottom and appear as a red spot. Hemagglutinating activity causes cell aggregation, resulting in a plaque of cells in the well [12].

2.3. Sugar Specificity Test. Twofold serial dilution of protein sample was performed using $50 \mu \mathrm{L}$ PBS containing $500 \mathrm{mM}$ solutions of different carbohydrates, and assay of hemagglutinating activity was performed. Competitive inhibition causes reduction of hemagglutinating activity of the protein. Then, twofold serial dilution of protein sample was performed using $50 \mu \mathrm{L}$ PBS containing different concentrations of the specific carbohydrate, and assay of hemagglutinating activity was performed to deduce the strength of inhibitory effect of the carbohydrate [13].

2.4. Sodium Dodecyl Sulphate Polyacrylamide Gel Electrophoresis. Protein sample was added to loading buffer containing $\beta$-mercaptoethanol and boiled for $10 \mathrm{~min}$ for denaturation. The sample was loaded onto a $15 \%$ polyacrylamide gel, and SDS-PAGE was performed at constant voltage of $120 \mathrm{~V}$ for $80 \mathrm{~min}$. The gel was stained with Coomassie Brilliant Blue for $1 \mathrm{hr}$ and destained with $10 \%$ acetic acid overnight [14].

2.5. MTT Assay. Breast cancer MCF7 cells were purchased from American Type Culture Collection (ATCC). A poorly differentiated Epstein-Barr virus (EBV) negative nasopharyngeal squamous carcinoma CNE2 cell line was purchased from the Sun Yat-Sen University of Medicinal Sciences, Guangzhou, China. Another poorly differentiated EBV positive nasopharyngeal squamous carcinoma cell line raised from another nasopharyngeal carcinoma (NPC) patient, HONE1, was generously provided by the Department of
Anatomy, The University of Hong Kong. Human skin fibroblast HSF98 cells were provided by the Department of Obstetrics and Gynaecology, The Chinese University of Hong Kong. MCF7, HONE1, CNE2, and HSF98 cells were seeded onto a 96-well plate overnight, and different concentrations of the lectin were added and the mixture was incubated for 24,48 , or $72 \mathrm{hr}$. The media were removed, and $25 \mu \mathrm{L}$ of $5 \mathrm{mg} / \mathrm{mL}$ MTT in PBS was added to the cells and incubated for $4 \mathrm{hr}$. Then $150 \mu \mathrm{L}$ DMSO wells were added and OD $580 \mathrm{~nm}$ was read using a microplate reader [15].

2.6. Flow Cytometry. HONE1 cells were seeded onto a 6well plate overnight, and different concentrations of the lectin were added for a $48 \mathrm{hr}$ treatment. The cells were trypsinized and washed with PBS. For Annexin V-FITC and PI staining, $250 \mu \mathrm{L}$ binding buffer containing $1.25 \mu \mathrm{L}$ Annexin V-FITC and $0.5 \mu \mathrm{L}$ PI were added to the cells and incubated in the dark for $15 \mathrm{~min}$. For JC-1 staining, $250 \mu \mathrm{L}$ of PBS containing $2.5 \mu \mathrm{g} / \mathrm{mL}$ JC-1 was added to the cells and incubated in the dark for $15 \mathrm{~min}$. Cells were analyzed by a BD LSRFortessa Cell Analyzer [16].

\section{Results}

Isolation of the lectin from Green Dragon no. 8 beans involved three chromatographic steps. Crude extract of the beans underwent affinity chromatography on Affi-gel blue gel. The lectin was adsorbed on the gel, allowing removal of majority of the beans' pigments that were eluted as the flowthrough. The bound fraction with the lectin underwent FPLC-anion exchange chromatography on Mono Q. At $\mathrm{pH}$ 7.6, a $\mathrm{pH}$ value probably higher than the isoelectric point of the lectin, the lectin was negatively charged and adsorbed onto the column and was eluted at around $0.25 \mathrm{M} \mathrm{NaCl}$ (Figure 1(a)). The fraction underwent FPLC-gel filtration on Superdex 75, and the lectin was eluted at around the 9th $\mathrm{mL}$ (Figure 1(b)). The calibration curve of the column revealed the molecular size of the lectin to be around $60 \mathrm{kDa}$. The fraction yielded a $30 \mathrm{kDa}$ band on SDS-PAGE (Figure 2). Therefore, the lectin should be a dimeric $60 \mathrm{kDa}$ protein. The above purification protocol yielded around $68 \mathrm{mg}$ lectin from $100 \mathrm{~g}$ beans and achieved a 20.8-fold purification (Table 1).

Carbohydrate specificity test through competing inhibition of the hemagglutinating activity of the lectin toward red blood cells revealed that the lectin was glucosamine specific, but not specific toward glucose, mannose, galactose, rhamnose, maltose, arabinose, $\mathrm{N}$-acetyl-galactosamine, $\alpha$-methylpyranoside, raffinose, mannitol, and xylitol. Besides, $250 \mathrm{mM}$ glucosamine was required to give detectable inhibition of the hemagglutinating activity (Figure 3 ).

Green Dragon no. 8 bean lectin exhibited antiproliferative activity on several tumor cell lines. It inhibited breast cancer MCF7 cells after treatment for 24, 48, and $72 \mathrm{hr}$ with $\mathrm{IC}_{50}$ values of $65.2 \mu \mathrm{M}, 33.9 \mu \mathrm{M}$, and $15.7 \mu \mathrm{M}$, respectively (Figure 4(a)). It also inhibited nasopharyngeal carcinoma HONE1 cells after treatment for 24,48 , and $72 \mathrm{hr}$ with $\mathrm{IC}_{50}$ values of $62.3 \mu \mathrm{M}, 31.6 \mu \mathrm{M}$, and $28.7 \mu \mathrm{M}$, respectively (Figure 4(b)). It also slightly affected nasopharyngeal carcinoma CNE2 cells, after treatment for 24 and $48 \mathrm{hr} .80 \mu \mathrm{M}$ 
TABle 1: Table of purification of the lectin from Green Dragon no. 8 beans.

\begin{tabular}{|c|c|c|c|c|c|}
\hline & $\begin{array}{c}\text { Yield } \\
(\mathrm{mg} / 70 \mathrm{~g} \text { beans }) \\
\end{array}$ & $\begin{array}{c}\text { Specific hemagglutinating } \\
\text { activity (unit/mg) }\end{array}$ & $\begin{array}{l}\text { Total hemagglutinating } \\
\left.\text { activity ( } 10^{5} \text { units }\right)\end{array}$ & $\%$ recovery & $\begin{array}{c}\text { Fold of } \\
\text { purification }\end{array}$ \\
\hline Crude extract & 8800 & 402 & 35.39 & 100 & 1 \\
\hline Affi-gel blue gel & 828 & 2731 & 22.61 & 63.9 & 6.8 \\
\hline Mono Q & 147.7 & 4915 & 7.26 & 20.5 & 12.2 \\
\hline Superdex 75 & 47.5 & 8356 & 3.97 & 11.2 & 20.8 \\
\hline
\end{tabular}

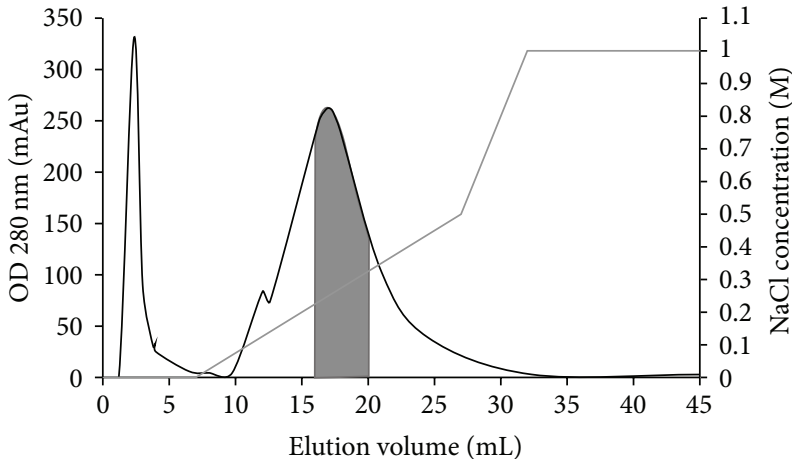

(a)

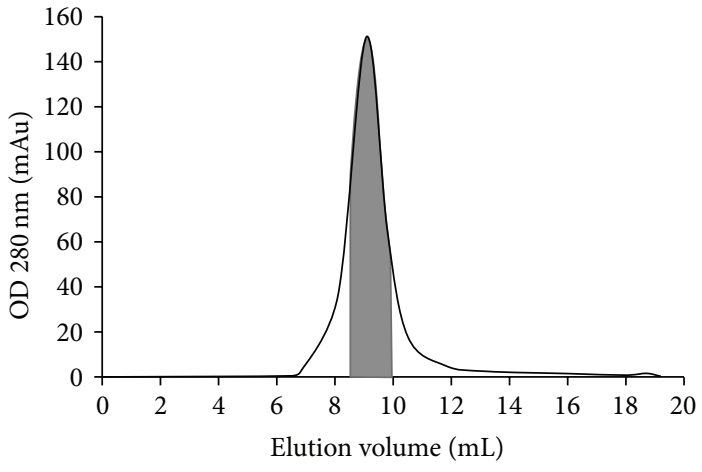

(b)

FIgURE 1: Profile of elution on purification of the lectin from Green Dragon no. 8 beans on (a) Mono Q column and (b) Superdex 75 column. The shaded area represents the fractions that constituted the lectin.

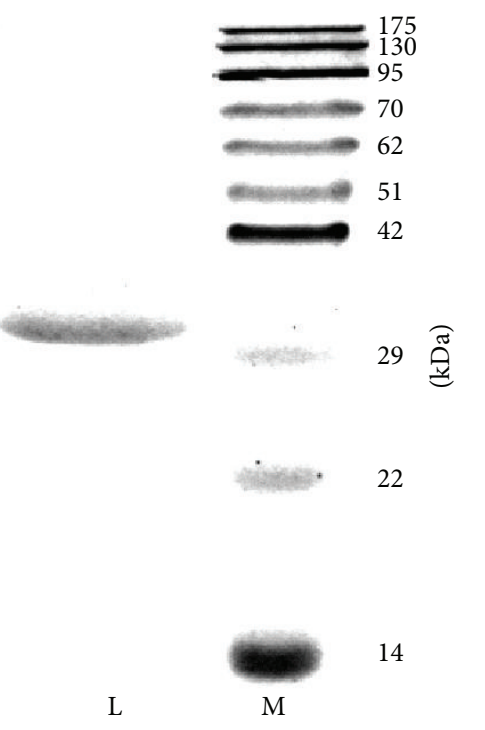

Figure 2: Results of SDS-PAGE on the lectin. Lane L: lectin presented in the target fraction eluted from Superdex 75. Lane M: protein ladder.

of the lectin caused around $20 \%$ and $40 \%$ reduction of the cell viability, while a $72 \mathrm{hr}$ treatment of the lectin raised a more obvious inhibitory effect with an $\mathrm{IC}_{50}$ value of $34.6 \mu \mathrm{M}$ (Figure 4(c)). On the other hand, the antiproliferative activity of the lectin on normal human skin fibroblast HSF98 cells was much lower compared with that on the aforementioned tumor cell lines. A slight inhibition could be observed on the cells until the lectin concentration was raised to $80 \mu \mathrm{M}$

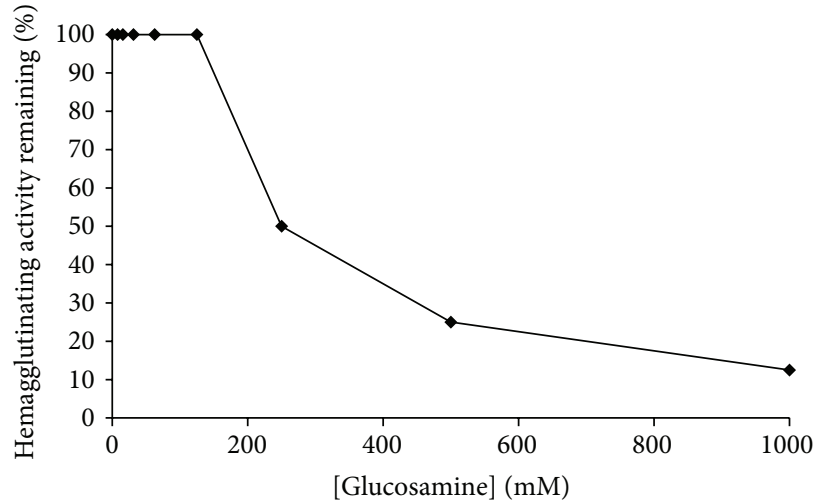

FIGURE 3: Effect of glucosamine on the hemagglutinating activity of the lectin.

under a 24 and $48 \mathrm{hr}$ treatment. Also, the $\mathrm{IC}_{50}$ value under a $72 \mathrm{hr}$ lectin treatment was also beyond $80 \mu \mathrm{M}$ (Figure $4(\mathrm{~d})$ ). This indicated the relative low toxicity of Green Dragon no. 8 lectin on the normal cell line, while the lectin was effective in inhibition of tumor cell lines.

Green Dragon no. 8 bean lectin induced signs of apoptosis on HONE1 cells which were detected by flow cytometry. Upon Annexin V-FITC and PI staining of the cells treated with increasing concentrations of the lectin, there was shifting of the cells from the lower left quadrant (Q3) to the right (Q4), indicating increasing intensity of green fluorescence signal from Annexin V-FITC, which implied an increase in Annexin $\mathrm{V}$ binding to phosphatidylserine, which is exposed on the cell surface during early apoptosis. The amount of 


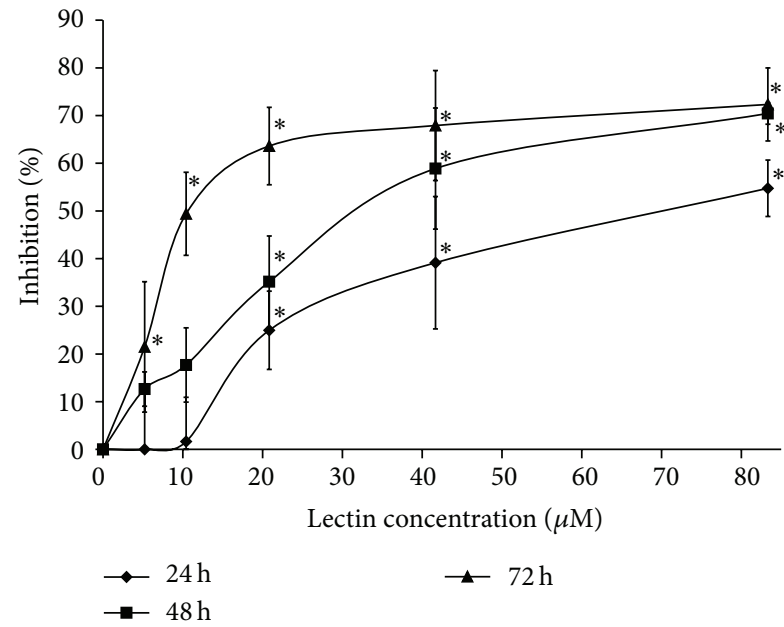

(a)

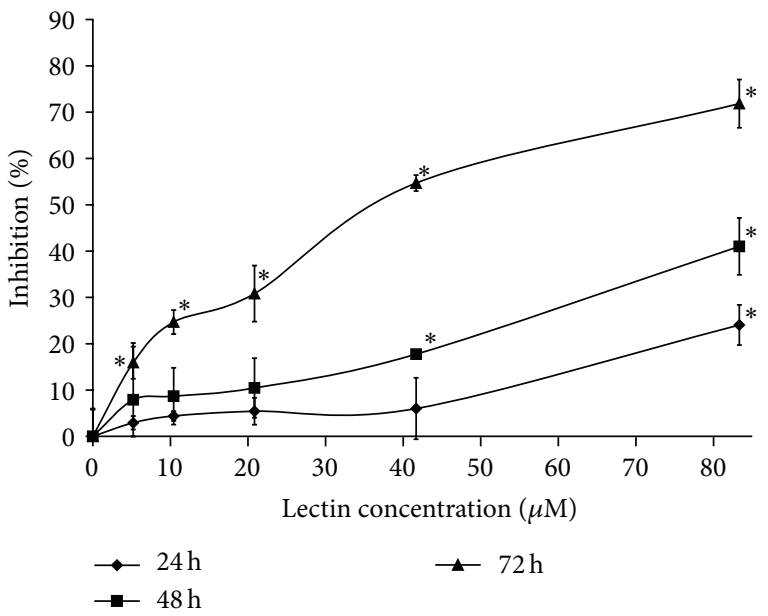

(c)

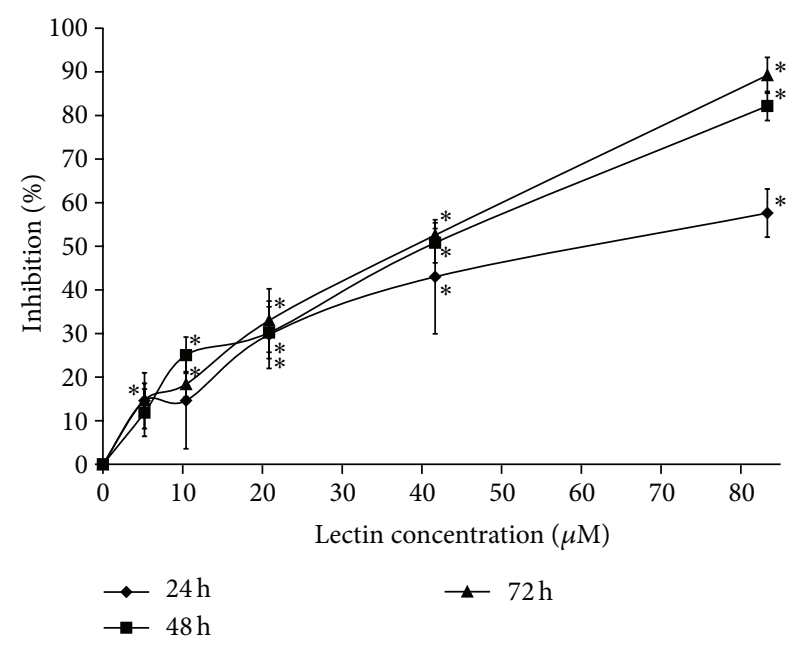

(b)

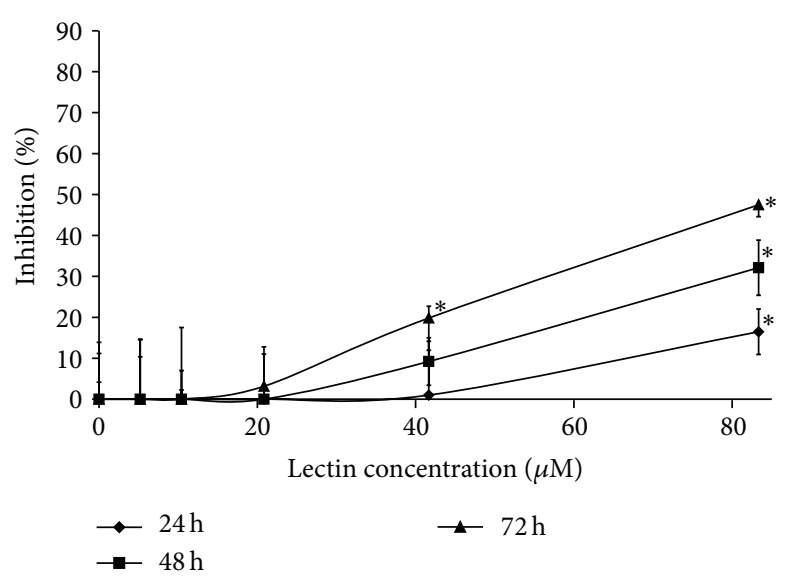

(d)

FIGURE 4: Results of MTT assay on (a) MCF7 cells, (b) HONE1 cells, (c) CNE2 cells, and (d) HSF98 cells upon treatment of the lectin for time intervals. Data represent mean \pm SD $(n=3)$. Data points marked with $*$ represent $p<0.05$.

cells at the upper right quadrant (Q2) also had increased after treatment with increasing concentrations of the lectin, which indicated that more cells were entering late apoptosis or dying under the lectin's activity (Figure 5(a)). Upon JC1 staining, the cells treated with increasing concentration of the lectin showed escalating intensity of green fluorescence signal. JC-1 is membrane permeable and positively charged and tends to accumulate in the electronegative interior of mitochondria, where it can form aggregates that emit red fluorescence. It emits red fluorescence in healthy cells with normal mitochondrial potential. Under certain conditions (e.g., apoptosis), opening of the mitochondrial permeability transition pores allows ion passage and causes disruption of mitochondrial potential. The change in ionic status caused JC-1 to stay in the monomeric form that emits green fluorescence. Upon JC-1 staining, healthy cells should present a low level of green fluorescence, while apoptotic cells probably show increased green fluorescence. Treatment of Green Dragon no. 8 bean lectin caused an increase in green fluorescence intensity, indicating that the lectin could cause mitochondrial depolarization during induction of apoptosis in HONE1 cells (Figure 5(b)). After PI staining of fixed lectin-treated HONE1 cells, the majority of cells at the first intensity peak at the left were at $G_{0} / G_{1}$ phase, while the cells at $G_{2} / M$ phase had doubled genetic materials and had doubled fluorescence intensity, and the cells at $S$ phase had the intensity between the two peaks. After treatment with higher lectin concentration, the proportion of cells at $G_{0} / G_{1}$ phase had decreased, while that at $G_{2} / M$ phase had increased (Figure 5(c)). MTT assay implied that the cell viability had decreased upon the treatment. Thus the lectin probably did not induce HONE1 cell proliferation but blocked the cells from dividing and kept them at the $\mathrm{G}_{2} / \mathrm{M}$ phase.

\section{Discussion}

Green Dragon no. 8 beans were purchased from a store in Guangdong, China. Mainland China is one of the countries that produce most kidney beans in the world, and a variety of $P$. vulgaris cultivars can be found. Besides the most 

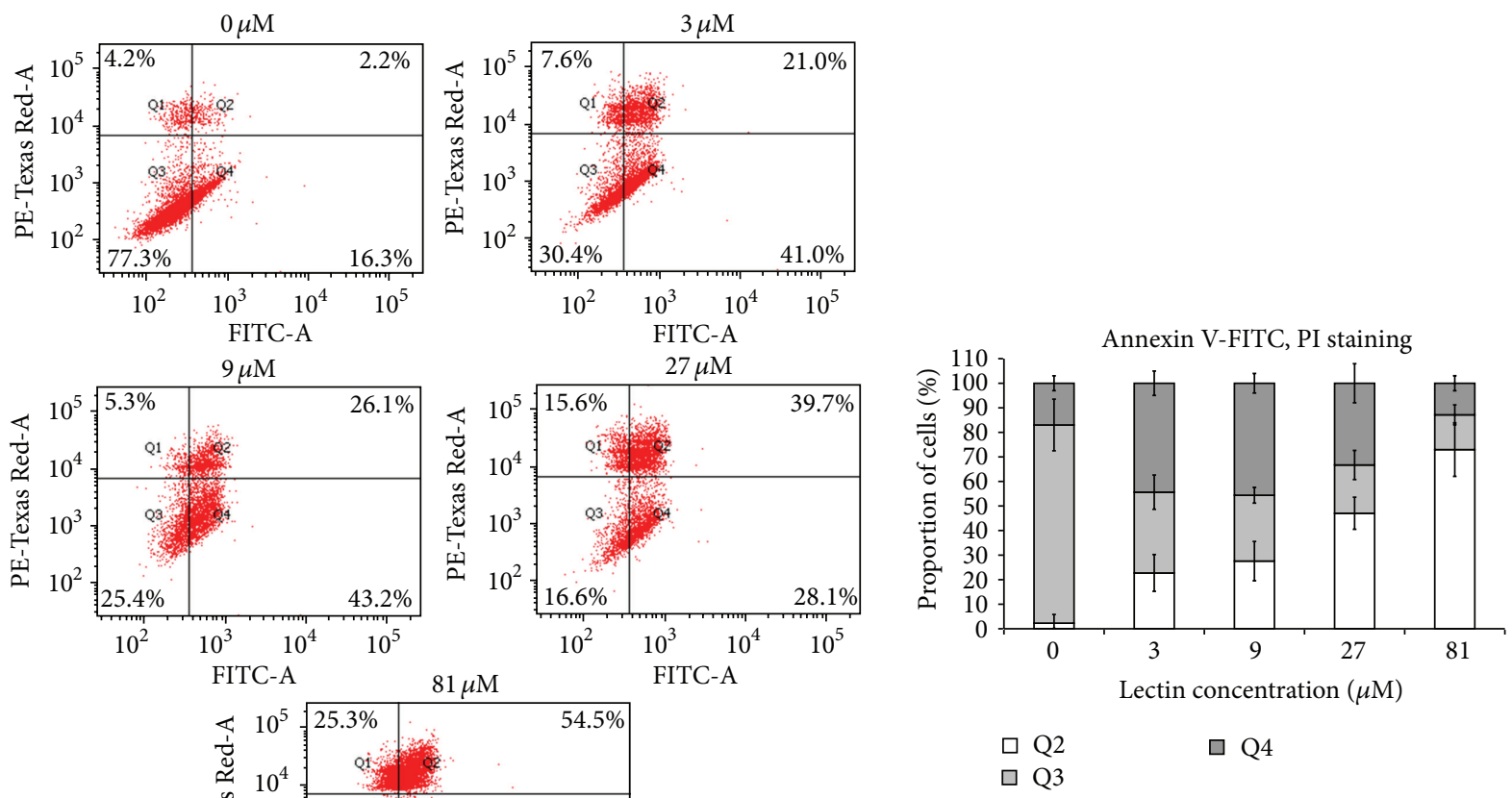

(a)
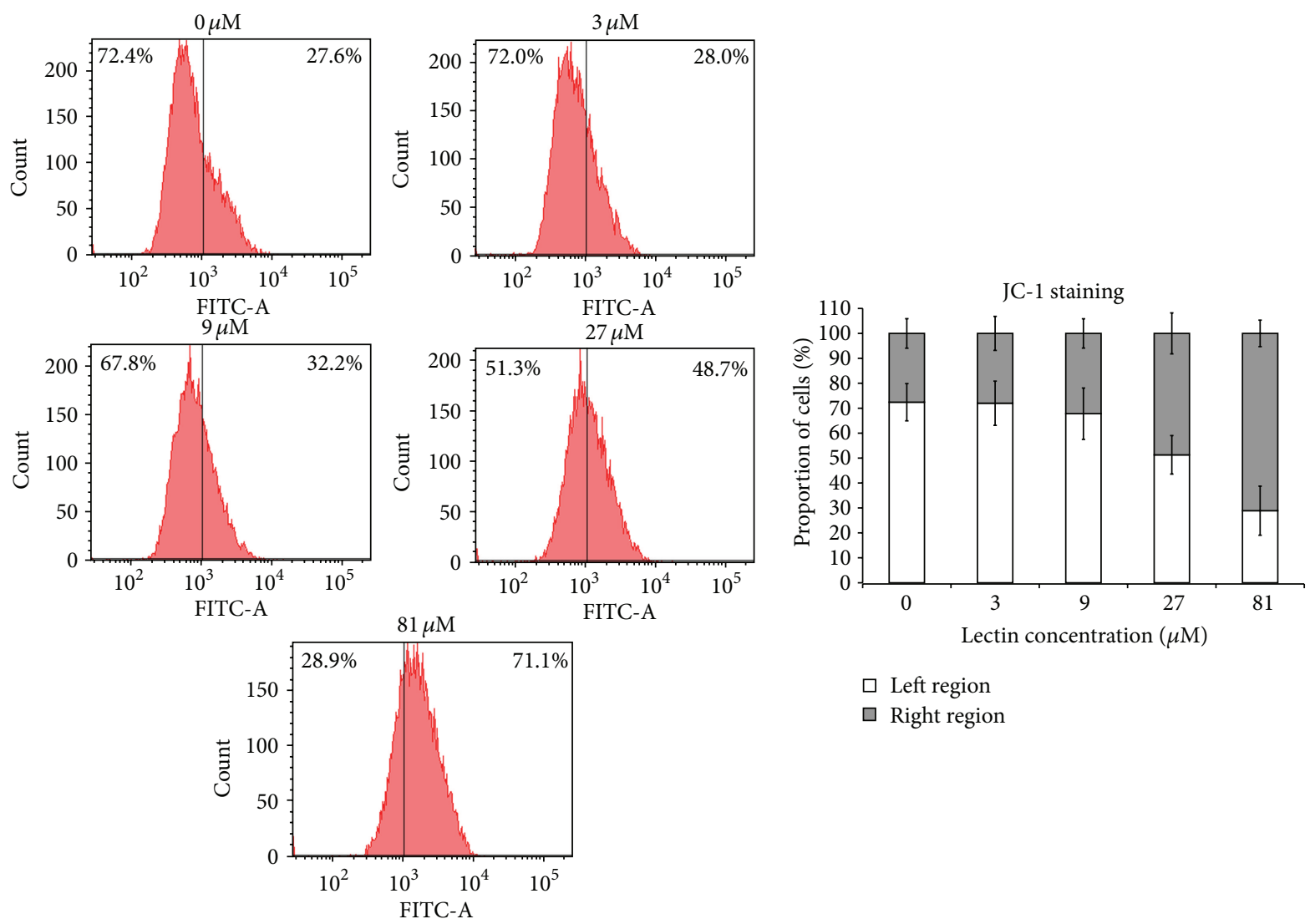

$\square$ Left region
$\square$ Right region

(b)

FIGURE 5: Continued. 

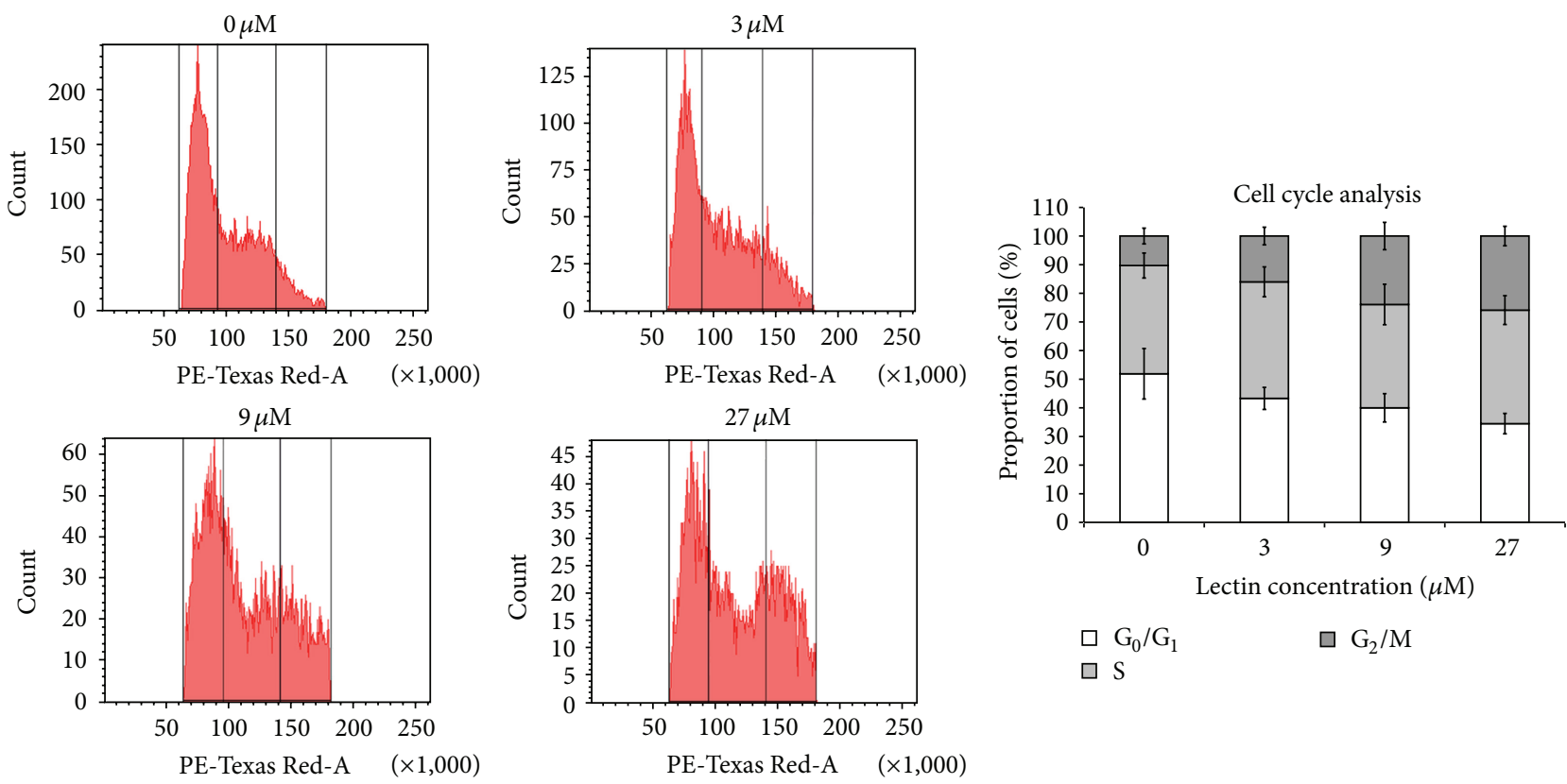

(c)

FIGURE 5: Results of flow cytometry on (a) Annexin V-FITC staining, (b) JC-1 staining, and (c) cell cycle analysis on HONE1 cells treated with the lectin for $48 \mathrm{hr}$. The bar charts represent proportion of cells located on each of the regions. Data represent mean $\pm \mathrm{SD}(n=3)$.

well-studied, common ones, for example, red kidney beans, that are grown worldwide, there are some rare cultivars, for example, Chinese pinto beans and blue tiger king beans, which are only found in China $[17,18]$. Green Dragon no. 8 bean is also a new, rarer $P$. vulgaris cultivar that is only present there. We established the first study on the proteins in this bean.

The purified lectin from Green Dragon no. 8 beans was found to be a $60 \mathrm{kDa}$ glucosamine-binding lectin. Though having similar molecular sizes to most of other $P$. vulgaris lectins, it has a relatively uncommon sugar specificity among the various lectins, together with Chinese pinto bean lectin and brown kidney bean lectin $[9,17]$. Green Dragon no. 8 lectin had lower specific hemagglutinating units ( $8356 \mathrm{unit} / \mathrm{mg}$ ) than that of Chinese pinto bean (202735 unit/mg) and brown kidney bean (32649 unit/mg) $[9,17]$. It also required a much higher concentration of glucosamine $(250 \mathrm{mM})$ than Chinese pinto bean lectin $(20 \mathrm{mM})$ and brown kidney bean lectin $(12.5 \mathrm{mM})$ to induce the hemagglutinating activity toward rabbit red blood cells [9, 17]. All these 3 lectins could induce antiproliferative effect on nasopharyngeal carcinoma cell lines. A $48 \mathrm{hr}$ treatment of Green Dragon no. 8 lectin on HONE1 cells resulted in an $\mathrm{IC}_{50}$ value of $31.6 \mu \mathrm{M}$, while Chinese pinto bean lectin gave rise to an $\mathrm{IC}_{50}$ value of $17.3 \mu \mathrm{M}$ [17]. On the other hand, a $48 \mathrm{hr}$ treatment of $80 \mu \mathrm{M}$ Green Dragon no. 8 lectin on CNE2 cells caused only $\sim 40 \%$ inhibition on the cells, while similar treatment of brown kidney bean lectin could achieve an $\mathrm{IC}_{50}$ value of $6.64 \mu \mathrm{M}$ [9]. The glucosamine-binding capability of brown kidney bean lectin was found to be crucial to its antiproliferative activity. It is highly possible for Green Dragon no. 8 lectin to show similar characteristics. Compared with the other two lectins, Green Dragon no. 8 lectin has a milder hemagglutinating activity as well as antiproliferative activity. A high hemagglutinating activity from raw, active form of the lectin could cause poisoning as the lectin can bind onto the intestinal cells [19]. Green Dragon no. 8 lectin, having a lower specific hemagglutinating activity, may show a lower side effect than the other two lectins during intake into the body.

Though Chinese pinto bean lectin and brown kidney bean lectin had potent antiproliferative activity on nasopharyngeal carcinoma cell lines, the studies of the effects of these two lectins on the cancer cells were not in depth. Here we found that Green Dragon no. 8 lectin induced apoptosis on HONE1 cells, as detected by phosphatidylserine externalization and mitochondrial depolarization, as well as cell cycle arrest at $\mathrm{G}_{2} / \mathrm{M}$ phase. These observations showed the effectiveness of the lectin to suppress the growth of nasopharyngeal carcinoma. There were very few reports on the use of lectins to inhibit this type of tumor. This report, together with the previous study on the Chinese pinto bean lectin and brown kidney bean lectin $[9,17]$, may give an insight into the application of glucosamine-specific lectins to treat nasopharyngeal carcinoma.

The various parts of the plant Phaseolus vulgaris L. commonly known as the kidney bean have been employed in Ayurvedic and Unani practice in India for antidiabetic therapy $[20,21]$. Phaseolus vulgaris can also be used for 11 inducing weight loss $[22,23]$. We have shown herein that it has anticancer effects.

\section{Conclusion}

Green Dragon no. 8 beans contained a glucosamine-binding lectin that could induce apoptosis on nasopharyngeal carcinoma cell lines. Similarly, some other glucosamine-binding 
lectins (Chinese pinto bean lectin and brown kidney bean lectin) also exhibited antiproliferative effects on those cells. Application of glucosamine-binding lectins may be an approach of nasopharyngeal cancer treatment.

\section{Conflict of Interests}

The authors declare that there is no conflict of interests regarding the publication of this paper.

\section{Acknowledgments}

This study is supported by the funding of the National Nature Science Foundation of China (NSFC) (no. 81273275) and matching funds of Shenzhen city (no. 006995).

\section{References}

[1] M. Bouchenak and M. Lamri-Senhadji, "Nutritional quality of legumes, and their role in cardiometabolic risk prevention: a review," Journal of Medicinal Food, vol. 16, no. 3, pp. 185-198, 2013.

[2] U. Singh, "Antinutritional factors of chickpea and pigeonpea and their removal by processing," Plant Foods for Human Nutrition, vol. 38, no. 3, pp. 251-261, 1988.

[3] E. O. Mello, S. F. F. Ribeiro, A. O. Carvalho et al., "Antifungal activity of PvD1 defensin involves plasma membrane permeabilization, inhibition of medium acidification, and induction of ROS in fungi cells," Current Microbiology, vol. 62, no. 4, pp. 1209-1217, 2011.

[4] V. D. S. Ramos, O. G. Cabrera, E. L. O. Camargo et al., "Molecular cloning and insecticidal effect of Inga laurina trypsin inhibitor on Diatraea saccharalis and Heliothis virescens," Comparative Biochemistry and Physiology $-C$ Toxicology and Pharmacology, vol. 156, no. 3-4, pp. 148-158, 2012.

[5] W.-T. Kuo, Y.-J. Ho, S.-M. Kuo et al., "Induction of the mitochondria apoptosis pathway by phytohemagglutinin erythroagglutinating in human lung cancer cells," Annals of Surgical Oncology, vol. 18, no. 3, pp. 848-856, 2011.

[6] H. Alizadeh, D. W. M. Leung, and A. L. J. Cole, "Conidiogenic effects of mannose-binding lectins isolated from cotyledons of red kidney bean (Phaseolus vulgaris) on Alternaria alternata," Phytochemistry, vol. 72, no. 1, pp. 94-99, 2011.

[7] J. Z. Castellanos, H. Guzman-Maldonado, E. G. de Mejia, and J. A. Acosta-Gallegos, "Effect of growing location on sensory properties and nutritional characteristics of black beans (Phaseolus vulgaris L.)," Archivos latinoamericanos de nutrición, vol. 45, no. 1, pp. 50-55, 1995.

[8] T. C. Osborn, J. W. S. Brown, and F. A. Bliss, "Bean lectins: 5. Quantitative genetic variation in seed lectins of Phaseolus vulgaris L. and its relationship to qualitative lectin variation," Theoretical and Applied Genetics, vol. 70, no. 1, pp. 22-31, 1985.

[9] Y. S. Chan, J. H. Wong, E. F. Fang, W. Pan, and T. B. Ng, "Isolation of a glucosamine binding leguminous lectin with mitogenic activity towards splenocytes and anti-proliferative activity towards tumor cells," PLOS ONE, vol. 7, no. 6, Article ID e38961, 2012.

[10] A. Sharma, J. H. Wong, P. Lin, Y. S. Chan, and T. B. Ng, "Purification and characterization of a lectin from the Indian cultivar of French bean seeds," Protein and Peptide Letters, vol. 17, no. 2, pp. 221-227, 2010.
[11] P. Lin, X. Ye, and T. Ng, "Purification of melibiose-binding lectins from two cultivars of Chinese black soybeans," Acta Biochimica et Biophysica Sinica, vol. 40, no. 12, pp. 1029-1038, 2008.

[12] S. X. Wang, G. Q. Zhang, S. Zhao et al., "Purification and characterization of a novel lectin with antiphytovirus activities from the wild mushroom Paxillus involutus," Protein and Peptide Letters, vol. 20, no. 7, pp. 767-774, 2013.

[13] F. Khan, A. Ahmad, and M. I. Khan, "Purification and characterization of a lectin from endophytic fungus Fusarium solani having complex sugar specificity," Archives of Biochemistry and Biophysics, vol. 457, no. 2, pp. 243-251, 2007.

[14] R. C. F. Cheung, H. H. Leung, W. L. Pan, and T. B. Ng, "A calcium ion-dependent dimeric bean lectin with antiproliferative activity toward human breast cancer MCF-7 Cells," Protein Journal, vol. 32, no. 3, pp. 208-215, 2013.

[15] C. Z. Zhang, E. F. Fang, H.-T. Zhang, L.-L. Liu, and J.-P. Yun, "Momordica Charantia lectin exhibits antitumor activity towards hepatocellular carcinoma," Investigational New Drugs, vol. 33, no. 1, article 156, pp. 1-11, 2015.

[16] S. Rafiq, R. Majeed, A. K. Qazi et al., "Isolation and antiproliferative activity of Lotus corniculatus lectin towards human tumour cell lines," Phytomedicine, vol. 21, no. 1, pp. 30-38, 2013.

[17] A. S. W. Ang, R. C. F. Cheung, X. Dan, Y. S. Chan, W. Pan, and T. B. Ng, "Purification and characterization of a glucosaminebinding antifungal lectin from Phaseolus vulgaris cv. Chinese Pinto Beans with antiproliferative activity towards nasopharyngeal carcinoma cells," Applied Biochemistry and Biotechnology, vol. 172, no. 2, pp. 672-686, 2014.

[18] E. F. Fang, W. L. Pan, J. H. Wong, Y. S. Chan, X. J. Ye, and T. B. $\mathrm{Ng}$, "A new Phaseolus vulgaris lectin induces selective toxicity on human liver carcinoma Hep G2 cells," Archives of Toxicology, vol. 85, no. 12, pp. 1551-1563, 2011.

[19] S. Bardocz, G. Grant, S. W. B. Ewen et al., "Reversible effect of phytohaemagglutinin on the growth and metabolism of rat gastrointestinal tract," Gut, vol. 37, no. 3, pp. 353-360, 1995.

[20] R. N. Chopra, I. C. Chopra, K. I. Handa, and L. D. Kapur, "Medicinal plants in diabetes," in Indigenous Drugs of India, pp. 314-316, Academic Publishers, 2nd edition, 1958.

[21] B. Longo-Mbenza and M. Muaka, "The protective effect of Phaseolus vulgaris on cataract in type 2 diabetes: a profitable hypothesis," Medical Hypothesis, Discovery \& Innovation Ophthalmology, vol. 2, no. 4, pp. 105-108, 2013.

[22] I. Onakpoya, S. Aldaas, R. Terry, and E. Ernst, "The efficacy of Phaseolus vulgaris as a weight-loss supplement: a systematic review and meta-analysis of randomised clinical trials," British Journal of Nutrition, vol. 106, no. 2, pp. 196-202, 2011.

[23] M. A. Tormo, I. Gil-Exojo, A. R. Romero de Tejada, and J. E. Campillo, "Hypoglycaemic and anorexigenic activities of an $\alpha$ amylase inhibitor from white kidney beans (Phaseolus vulgaris) in Wistar rats," British Journal of Nutrition, vol. 92, no. 5, pp. 785-790, 2004. 


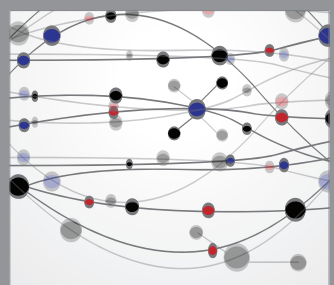

The Scientific World Journal
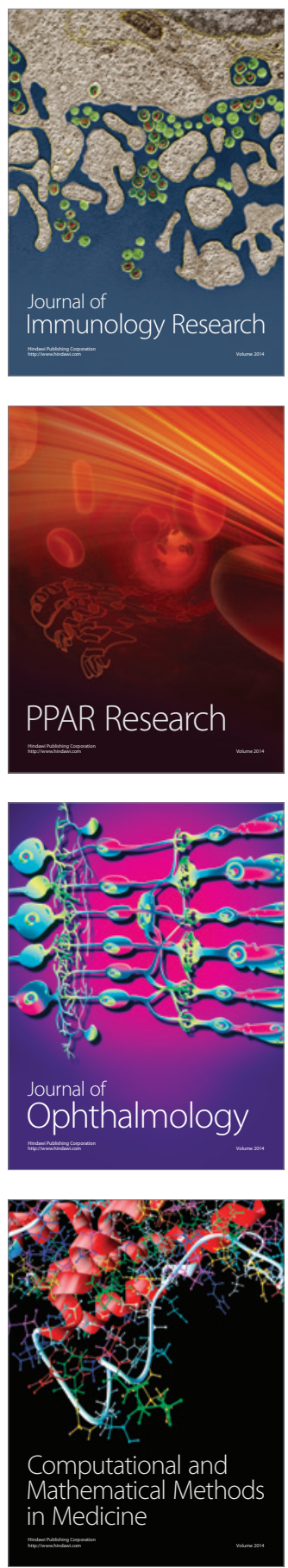

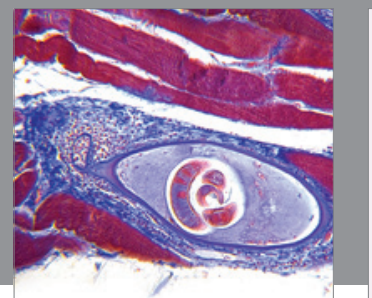

Gastroenterology

Research and Practice
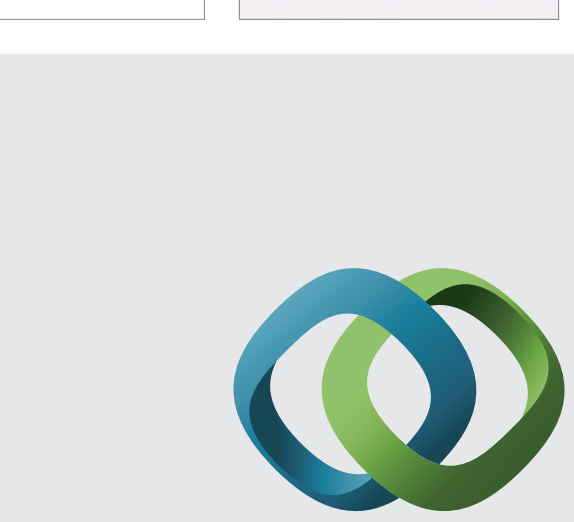

\section{Hindawi}

Submit your manuscripts at

http://www.hindawi.com
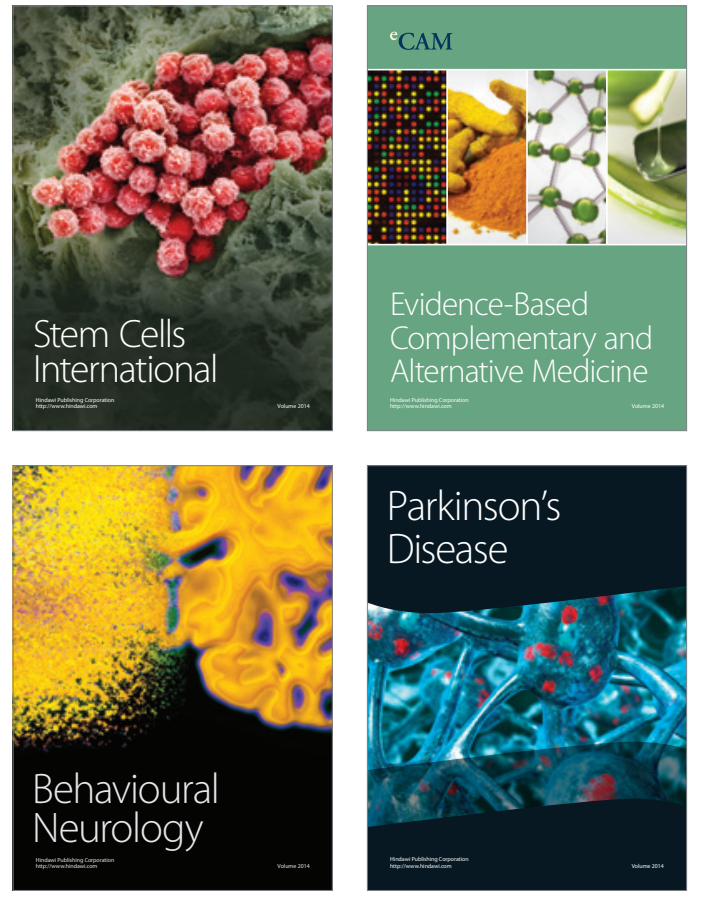
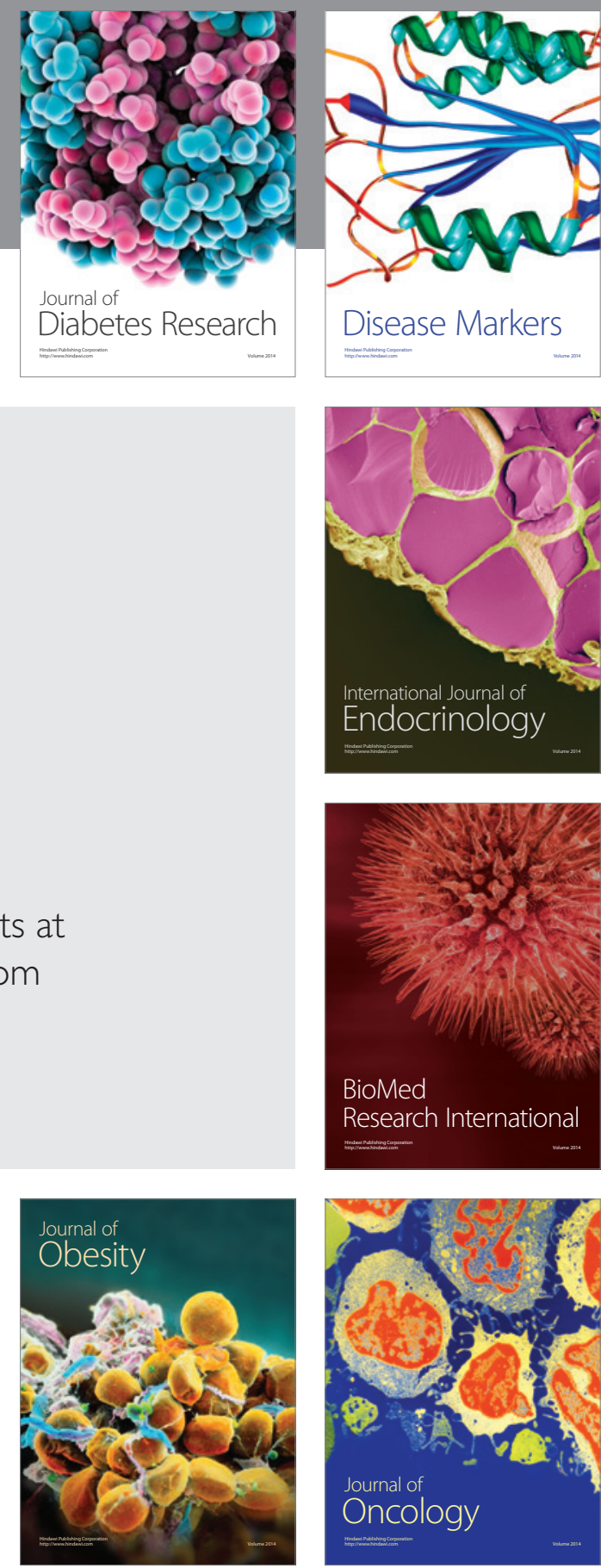

Disease Markers
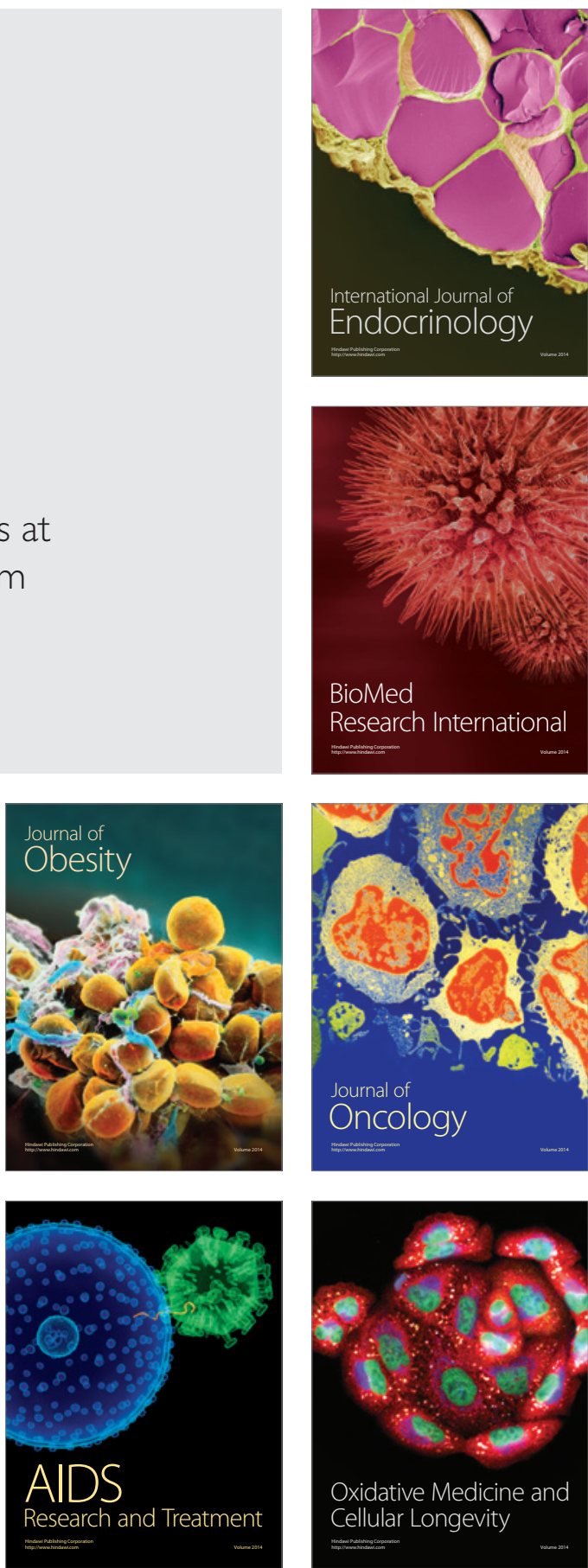